\title{
La historia se escribe con «i» de imágenes ${ }^{1}$
}

Irene Marrone y Susana Allegretti

En memoria de Tadeo Bortnowski, cama- miento en Polonia un 25 de mayo de I924, rógrafo y director artístico del noticiario y su arribo al país un 9 de julio de 1948 . cinematográfico Sucesos Argentinos, quien Nada sabía sin embargo sobre Argentina falleció el 2I de noviembre de 2015 . al llegar, ni su idioma, ni su cultura, pero eso no fue escollo para integrarse casi de Para los argentinos, Tadeo Bortnowski inmediato como camarógrafo al plantel bien podría ser recordado como parte de de uno de los principales noticiarios arla historia de esos pioneros de la inmi- gentinos del momento, Sucesos Argentinos gración europea que llegaron a nuestro (1938-1972). Es que, a pesar de su corta país luego de la Segunda Guerra Mundial edad, contaba al llegar con una vasta para incorporarse de lleno a la labor del noticiario sonoro argentino. Le gustaba decir que su destino estuvo marcado por dos fechas patrias bien criollas, su naciexperiencia acumulada en el quehacer cinematográfico como parte de los equipos de propaganda que filmaron en los campos de batalla durante la Segunda

1. Título de un anuario de recopilación de notas del noticiario Sucesos Argentinos. Recuerdo de Tadeo Bortnowski, sin fecha. 
Guerra Mundial para el bando aliado y en los entornos de los juicios de Nüremberg. Estos antecedentes sumados a una destacada labor en los primeros años, mediaron para que se convirtiera en poco tiempo y por muchos años (I95I-I972) en director artístico del mencionado noticiario. Su mayor orgullo, decía, era haber creado a instancias del gobernador de la provincia de Buenos Aires, Cnel. Domingo Mercante, el primer y único noticiario estatal, con más de Ioo números exhibidos durante diez años en los más de 500 cines de todo el país, noticiario que salió bajo gobiernos tan disímiles como el de Perón, la dictadura de la «revolución Libertadora» o el de Frondizi.

Si bien hoy reconocemos sin lugar a dudas el valor del noticiario cinematográfico argentino como principal medio audiovisual de "actualidades» de los años 40 y 50, ha quedado cristalizado en la memoria la idea errónea de que en realidad se trataba de propaganda peronista. Más ajustado sería decir que estos noticiarios fueron la voz oficial de todos los gobiernos, pero su configuración estaba copiada de lo que extraían como noticias de los grandes medios gráficos, como La Nación, Clarín, La época, Crítica $\mathrm{y}$ otros tantos, quienes eran los forjadores originales de una opinión que luego el noticiario reproducía como «sentido común», o mejor, como expresión del orden dominante. Todos los gobiernos desde I943 hasta 1972 les otorgaron subsidios y el privilegio de la exhibición obligatoria en las salas de cine, como contrapartida estos publicitaban los actos de gobiernos junto a notas de interés general, de tipo cultural, deportivas, turísticas, económicas, etc. Para Tadeo Bornowski, la censura como sugerencia directa del poder no existió, solía decir que «no hacíamos lo que arriba no iba a gustar», en tanto decía también que nunca hubieran hecho concesiones de tipo éticas, «no hacíamos cosas burdas, que engañaran a la gente».

Durante su estadía en Sucesos Argentinos Bortnowski dio mucha importancia y se ocupó personalmente de las notas que intercambiaba con noticiarios del exterior, notas que venían de Francia, Inglaterra, España, Polonia, con más de 32 países, entre los cuales durante la guerra fría se hacía con noticiarios tanto del mundo capitalista como del comunista. Con la cámara en mano, le gustaba decir que no distinguía el peligro, «sólo trataba de hacer lo mejor», además siempre evitaba mandar a otros camarógrafos cuando era cuestión de vida, fue así que filmó los bombardeos en Plaza de Mayo donde murieron centenares de argentinos, o cuando estallaron las bombas durante un discurso de Perón en esta misma plaza en agosto de 1955 .

Cuando su actividad en Sucesos Argentinos cesó, fundó su productora Notrus film, y se destacó con realizaciones valiosas desde el punto de vista cultural como el documental Borges, un destino 
sudamericano que contó con la participación del célebre escritor filmado en 1975. Original que permaneció inédito hasta que fue proyectado por primera vez en el marco de la muestra Registrando Olvidos patrocinada por la Casa América, dentro del Festival Documental, Madrid, 2007.

Para todos aquellos que nos interesamos por la memoria histórica que representan las imágenes y sonidos del noticiario, Tadeo Bortnowski fue quien nos abrió las puertas de su mundo hablándonos de su trayectoria, de su trabajo en Argentina, mostrándonos su colección de objetos, y permitiéndonos acceder a la historia de una documentación que revela la forma de trabajo de una época del audiovisual informativo. Entre muchos de quienes participaron de esta experiencia, fue quien más claro tuvo su lugar como transmisor de esa memoria convirtiéndose en un interlocutor privilegiado para estudiantes, investigadores, realizadores de cine y docentes, que vimos en ese acervo una expresión y una fuente valiosísima para la reconstrucción de fragmentos de nuestra historia.
La importancia de su labor se relaciona con nuestra identidad, su obra nos permite compartir ahora con sentido crítico el tiempo pasado, nos permite trabajar para cuidar un patrimonio histórico que registra algo de la historia de todos los días de los argentinos, historia que como ya se dijo fue siempre historia oficial. Su voz se sumó a los reclamos que por muchos años hicieron los apasionados del cine argentino, sobre la necesidad de contar con un archivo nacional que preservara sus imágenes como patrimonio cultural histórico de los argentinos.

Tadeo Bortnowski, se sentía tranquilo cuando, en 2009, testimoniando sobre su vida para la película Crónicas de una historia de vida (Trajtengartz y Martín, 2009) realizada en su honor comenzó su larga alocución diciendo «Mis sueños están cumplido, lo que resta, voy a dedicárselo a mi familia». Para ellos también nuestro agradecimiento ya que siempre nos sentimos muy bien recibidos cuando lo visitamos en su casa para que nos contara la historia de los pioneros del noticiario cinematográfico argentino.

\section{Referencias bibliográficas}

- KRIGER, C. (sf). El noticiero Sucesos Argentinos. Blog Historia política Disponible en: http://historiapolitica.com/datos/ biblioteca/kriger.pdf

- MARRONE, I.; MOYANO WALKER, M. (comps.) (2006a). Persiguiendo imágenes. El noticiario argentino, la memoria y la historia (1930-1960). Buenos Aires: Editores del Puerto. 
-___ (2006b). Perón, Mercante y el Noticiario Bonaerense. En Panella, C., El gobierno de Domingo A. Mercante en Buenos Aires (1946-1952). Un caso de peronismo provincial. La Plata: Archivo Histórico de la Provincia de Buenos Aires.

•-_- (eds.) (2007). Imágenes e imaginarios del Noticiario Bonaerense, 1948/1958. Instituto Cultural de la Provincia de Buenos Aires. La Plata: Archivo Histórico de la Provincia de Buenos Aires.

\section{Filmes}

- Crónicas de una historia de vida. Lucas Trajtengartz y Fernando H. Martín, 2009. Disponible en: https://youtu.be/d6gsPKAS5Kg

\section{Entrevistas}

- Vicente López, Buenos Aires, 22/07/2005. Ver en https:// youtu.be/Rt2GVDC4ECw : La historia se escribe con «i de imágenes". Realizada por Irene Marrone, con la asistencia de Pablo Schencmann, cámara de Leonardo Neumann y Sergio Damián. - Vicente López, Buenos Aires, 03/2007: Poco a poco la cámara conquista a todos. Realizada por Irene Marrone, Florencia Luchetti, y Fernando Ramírez Llorens. 